\title{
MULTILINGUA
}

\section{JOURNAL OF CROSS-CULTURAL}

AND INTERLANGUAGE COMMUNICATION

\section{EDITOR}

Ingrid Piller

Department of Linguistics

Macquarie University, Australia

EDITORIAL ASSISTANT

Hanna Irving Torsh

Macquarie University, Australia

EDITORIAL BOARD

Philipp Angermeyer

York University, Canada

Jinhyun Cho

Macquarie University, Australia

Eva Codó

Universitat Autònoma de Barcelona,

Spain

Alexandre Duchêne

Université de Fribourg, Switzerland

Ingrid Gogolin

Hamburg University, Germany

Alexandra Grey

University of Sydney, Australia

Nelson Flores

University of Pennsylvania, USA
Huamei Han

Simon Fraser University, Canada

Adam Jaworski

University of Hong Kong, China

Petteri Laihonen

University of Jyväskylä, Finland

Sabine Little

University of Sheffield, UK

Ikuko Nakane

University of Melbourne, Australia

Joseph Sung-Yul Park

National University of Singapore,

Singapore

Fatma Said

Goldsmiths, University of London, University of York, UK

Laura Smith-Khan

University of Technology Sydney,

Australia

Jie Zhang

Zhongnan University of Economics and Law, PR China

\section{DE GRUYTER \\ MOUTON}


ABSTRACTED/INDEXED IN Baidu Scholar · BLL Bibliographie Linguistischer Literatur · Cabell's Whitelist · CNKI Scholar (China National Knowledge Infrastructure) · CNPIEC: cnpLINKer .

Dimensions · EBSCO (relevant databases) · EBSCO Discovery Service · ERIC (Education Resources Information Center) · ERIH PLUS (European Reference Index for the Humanities and Social Sciences) · Gale/Cengage · Genamics JournalSeek · Germanistik · Google Scholar · IBR (International Bibliography of Reviews of Scholarly Literature in the Humanities and Social Sciences) · IBZ (International Bibliography of Periodical Literature in the Humanities and Social Sciences) - Index Copernicus · International Bibliography of the Social Sciences (ProQuest) $\cdot$ J-Gate $\cdot$ Journal Citation Reports/Social Sciences Edition · JournalGuide · JournalTOCs · KESLI-NDSL (Korean National Discovery for Science Leaders) · Linguistic Bibliography $\cdot$ Linguistics Abstracts Online · Microsoft Academic $\cdot$ MLA International Bibliography $\cdot$ MyScienceWork $\cdot$ Naver Academic $\cdot$ Naviga (Softweco) · Norwegian Register for Scientific Journals, Series and Publishers · OLC Linguistik · Primo Central (ExLibris) · ProQuest (relevant databases) · Publons · QOAM (Quality Open Access Market) - ReadCube - SCImago (SJR) - SCOPUS · Semantic Scholar · Sherpa/RoMEO - Summon (ProQuest) · TDNet · Ulrich's Periodicals Directory/ulrichsweb · WanFang Data - Web of Science: Arts \& Humanities Citation Index; Social Sciences Citation Index · WorldCat (OCLC)

The publisher, together with the authors and editors, has taken great pains to ensure that all information presented in this work reflects the standard of knowledge at the time of publication. Despite careful manuscript preparation and proof correction, errors can nevertheless occur. Authors, editors and publisher disclaim all responsibility for any errors or omissions or liability for the results obtained from use of the information, or parts thereof, contained in this work.

ISSN 0167-8507 · e-ISSN 1613-3684

All information regarding notes for contributors, subscriptions, Open access, back volumes and orders is available online at www.degruyter.com/journals/multilin

RESPONSIBLE EDITOR Ingrid Piller, Department of Linguistics, Macquarie University, NSW 2109, Australia, e-mail: ingrid.piller@mq.edu.au

PUBLISHER Walter de Gruyter GmbH, Berlin/Boston, Genthiner Straße 13, 10785 Berlin, Germany

JOURNAL MANAGER Juliane Herzer, De Gruyter, Genthiner Straße 13, 10785 Berlin, Germany, Tel: +49 (0)30 260 05-380, Fax: +49 (0)30 260 05-250,

e-mail: juliane.herzer@ degruyter.com

RESPONSIBLE FOR ADVERTISEMENTS Kevin Göthling, De Gruyter, Genthiner Straße 13, 10785 Berlin, Germany, Tel.: +49 (0)30 260 05-170, e-mail: anzeigen@ degruyter.com

(C) 2020 Walter de Gruyter GmbH, Berlin/Boston, Germany

TYPESETTING TNQ Technologies, Chennai, India

PRINTING Franz X. Stückle Druck und Verlag e.K., Ettenheim

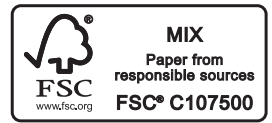




\section{Contents}

\section{Articles}

Benedict J.L. Rowlett

Second language socialization in the margins: Queering the paradigm — 631

Tuuli From

'We are two languages here.' The operation of language policies through spatial ideologies and practices in a co-located and a bilingual school -663

Holly HK Didi-Ogren

Sociocultural linguistic approaches to code switching in Japanese women's talk in interaction: Region, gender, and language -685

Syed Abdul Manan

Teachers as agents of transformative pedagogy: Critical reflexivity, activism and multilingual spaces through a continua of biliteracy lens -721

\section{Book Review}

\section{Zeyang Wang}

Machine translation and global research: Towards improved machine translation literacy in the scholarly community -749 